\title{
Empowerment of Fruits Management through the Increasing Economic Value of Local Product on the Red Guava Cluster
}

\author{
By: \\ Abdul Hoyyi ${ }^{1)}$, Darwanto ${ }^{2)}$ \\ ${ }^{1)}$ Faculty of Economics, Universitas Diponegoro \\ ${ }^{1)}$ Email: ahy_stat@undip.ac.id
}

\begin{abstract}
Kendal is one of the regencies in Central Java province, which has superior horticultural products, especially in the production of fruits. Kendal has some types of fruits including "Jambu biji Getas Merah" or red guava. Local communities, especially farmer community established Joint Farmer Group (Gapoktan) of red guava to process it into processed products. The purpose of this research was to analyze issues related to processing of guava in Tambahrejo village. The research used descriptive qualitative analysis with Participatory Rural Appraisal, PRA method. Data were obtained from in-depth interviews with key persons associated with the research. The results showed that based on the analysis of Hazard Analysis Critical Control Point (HACCP), processing of red guava could improve quality assurance and food safety of red guava processed product in order to keep developing the product and fulfill the requirements of consumers. Problems associated with the processing of red guava can be minimized or resolved by the establishment of institution in the community to process guava and cooperation between Gapoktan of red guava and the government, local communities and external parties such as educational institutions, investors and others.
\end{abstract}

Keywords: Red Guava, Gapoktan, HACCP, Institution.

\begin{abstract}
ABSTRAK
Kendal adalah salah satu kabupaten di Provinsi Jawa Tengah, yang memiliki produk hortikultura unggul, terutama dalam produksi buah-buahan. Kendal memiliki beberapa jenis buah-buahan termasuk "Jambu biji Getas Merah" atau jambu biji merah. Masyarakat lokal, khususnya masyarakat petani membentuk Kelompok Tani Gabungan (Gapoktan) jambu biji merah untuk mengolahnya menjadi produk olahan. Tujuan dari penelitian ini adalah untuk menganalisis masalah yang berkaitan dengan pengolahan jambu biji di desa Tambahrejo. Penelitian ini menggunakan analisis deskriptif kualitatif dengan Participatory Rural Appraisal, metode PRA. Data diperoleh dari wawancara mendalam dengan orang-orang kunci yang terkait dengan penelitian. Hasil penelitian menunjukkan bahwa berdasarkan analisis Hazard Analysis Critical Control Point (HACCP), pengolahan jambu biji merah dapat meningkatkan jaminan kualitas dan keamanan pangan produk olahan jambu biji merah agar dapat terus mengembangkan produk dan memenuhi persyaratan konsumen. Masalah yang terkait dengan pengolahan jambu biji merah dapat diminimalkan atau dipecahkan oleh pembentukan institusi di masyarakat untuk memproses jambu biji dan kerjasama antara Gapoktan jambu biji merah dan pemerintah, masyarakat lokal dan pihak eksternal seperti lembaga pendidikan, investor dan lain-lain.
\end{abstract}

Kata Kunci: Jambu Biji Merah, Gapoktan, HACCP, Institusi. 


\section{INTRODUCTION}

Kendal Regency is one of the regencies in Central Java Province which has superior horticultural products, especially fruits production. Kendal Regency has several types of fruit products, including guava. BPS data of Kendal Regency shows that guava production in Kendal Regency increased up to 64.04 percent compared to the previous year by 2014 or the number has reached 159,201 quintal/100 kg by 2015. Red guava is one type of guava existing in in several sub-districts of Kendal Regency, such as Patean, Sukorejo, Pageruyung, and Plantungan sub-districts. Red guava production in the four sub-districts has formed a cluster of red guava in Kendal Regency.

Tambahrejo village is red guava producing area located in Pageruyung sub-district. Tambahrejo village has an area of 310 ha and is located along the road connecting Waleri sub-district to Sukorejo sub-district, and connecting Kendal Regency to Temanggung Regency. Most of people of Tambahrejo village have a livelihood as farmers because most of the village area is agricultural land as shown in Figure 1. This indicates that the agricultural sector is the main potential that can be developed to improve the community welfare in Tambahrejo Village.

The development of the potential of Tambahrejo Village has been performed, including the processing red guava production into processed products in the form of jam, dried guava sweet, syrup, jenang (Indonesian snack), juice, sauce, guava brownies, egg roll, guava lunpia (spring roll with fillings), and so on and establishing a cooperation between farming groups to form red guava cluster in Kendal Regency. However, there are still some problems that can be obstacles in the development of red guava products. These problems include problems related to the processing of guava products. The objective of this research is to analyze the problems related to guava processing in Tambahrejo village.

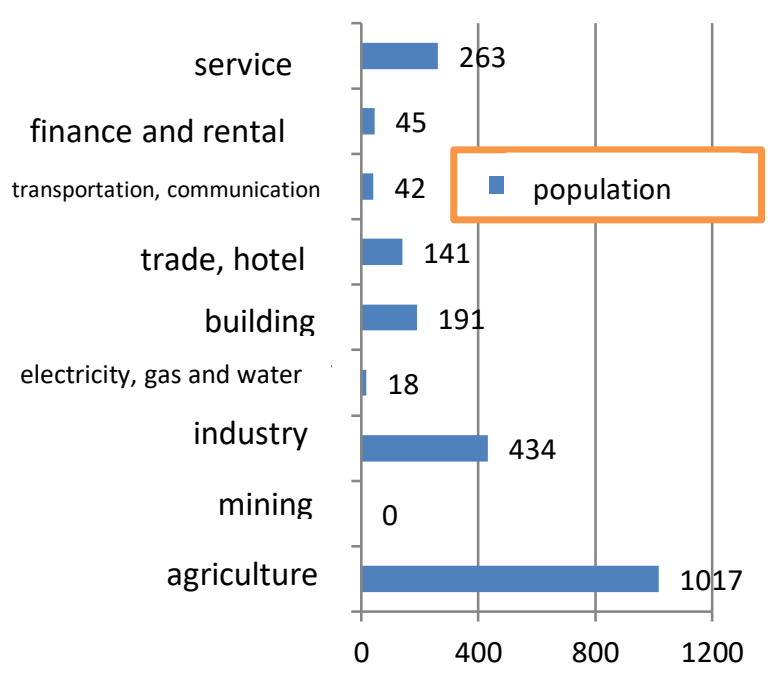

Figure 1. Population Based on Livelihoods in Tambahrejo Village in 2013

Source: BPS, 2014

\section{ANALYTICAL METHOD}

The method used in this research was descriptive qualitative analysis with Participatory Rural Appraisal approach, PRA. PRA is an approach that involves the community role in the implementation of activities. The stages of research implementation include: 1) Identification of problems based on survey and observation on the potential of Tambahrejo Village and interview with key person related to the research; 2) Data requirement analysis used in this research; 3) Preparation of the program in accordance with the problems related to the research in Tambahrejo Village; 4) Implementation of research program that is expected to provide solutions related to problems in Tambahrejo village; 5) Monitoring and evaluating the implementation of research program related to community empowerment to develop the potential of Tambahrejo Village; and 6) Research reporting to 
determine the success rate of the programs implementation related to the research in Tambahrejo Village.

\section{RESULT}

Agricultural sector is the leading sector in Tambahrejo Village with holticulture sub-sector products in the form of red guava production. Tambahrejo Village has three hamlets, namely Bogosari, Tembeleng, and Gunung Sari hamlets. Farmer institution in Tambahrejo Village has been developed shown by two farmer groups, namely Makmur 1 Farmer Group and Makmur 2 Farmer Group where each group has 50 members. The red guava farmers take about eight months to produce red guava. The problem occured during the harvest, the problem was the high price of grafted red guava seedling and equipment needed during the during the harvest, which was still traditional.

The local people of Tambahrejo Village processed red guava into processed products. The processing of red guava is performed with the aim to develop the innovation of farmers to increase the selling value of red guava so that consumers are interested in the processed products (Warsigit, 2010; Lalisang, 2017). Efforts to increase processed red guava also has a positive impact on the development of regional SME products (Ginting et al., 2007). One of the processed products of the village is jenang made of red guava. The process and stages of making jenang made of red guava are shown in Figure 2.

In the aspect of Hazard Analysis Critical Control Point (HACCP), Hazard Analysis Critical Control Point (HACCP) in red guava processing is aimed at improving quality assurance and food safety in order to keep developing in accordance with consumer requirements. Food safety is the main and most important requirement of all existing parameters. Food safety is a necessary condition and effort to prevent food from the possibility of biological, chemical and other contamination that may disrupt, harm and endanger health. The basic principles that guide the preparation of HACCP based on the proposal of the National Advisory Committee on Microbiological Criteria for Foods, NACMCP include; 1) hazard identification, hazard analysis and risk assessment as well as hazard prevention measures; 2 ) identification and determination of critical control points (CCP) on production activities; 3 ) the designation of critical limits in accordance with each identified CCP; 4) preparation of monitoring procedures and requirements as a form of supervision of the CCP; 5) designation/determination of corrective action that should be performed in case of deviation on the critical limit; 6) the implementation of the procedure effectively to take a record in the form of record keeping; and 7) the designation of procedures to test the truth. The determination of HACCP Application procedures is performed on red guava processed product, namely jambu jenang.

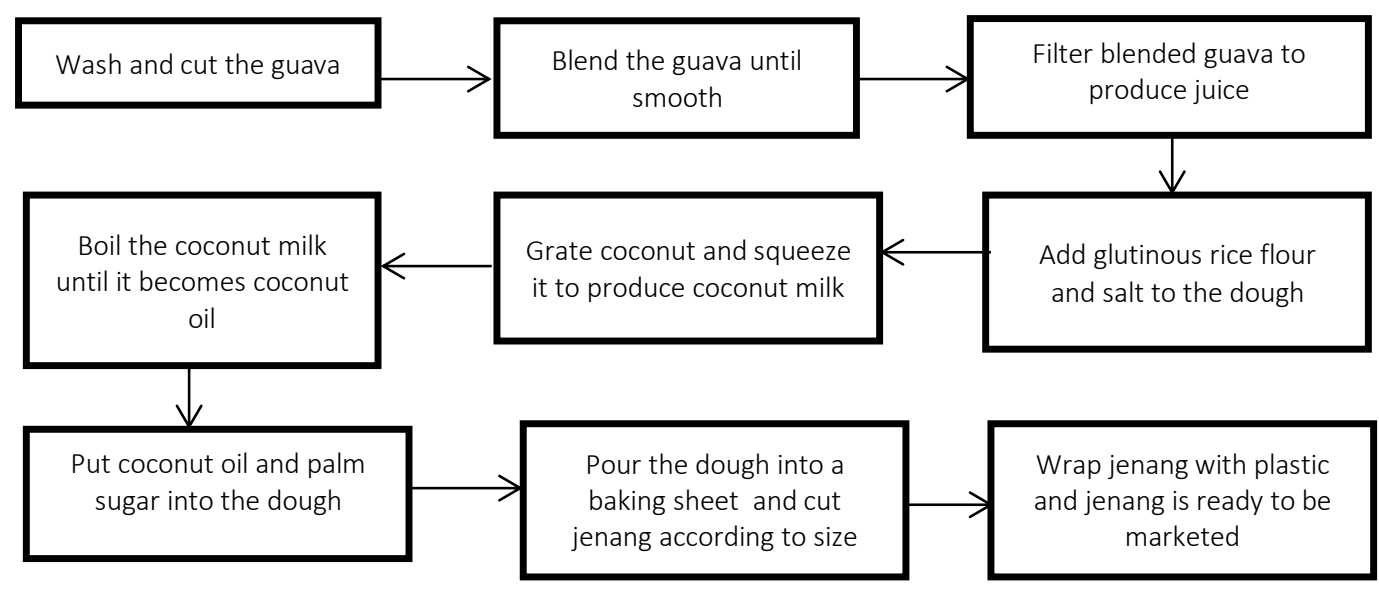

Figure 2. Process or Stages of Making Red Guava Jenang

Source: Data Processed, 2016 


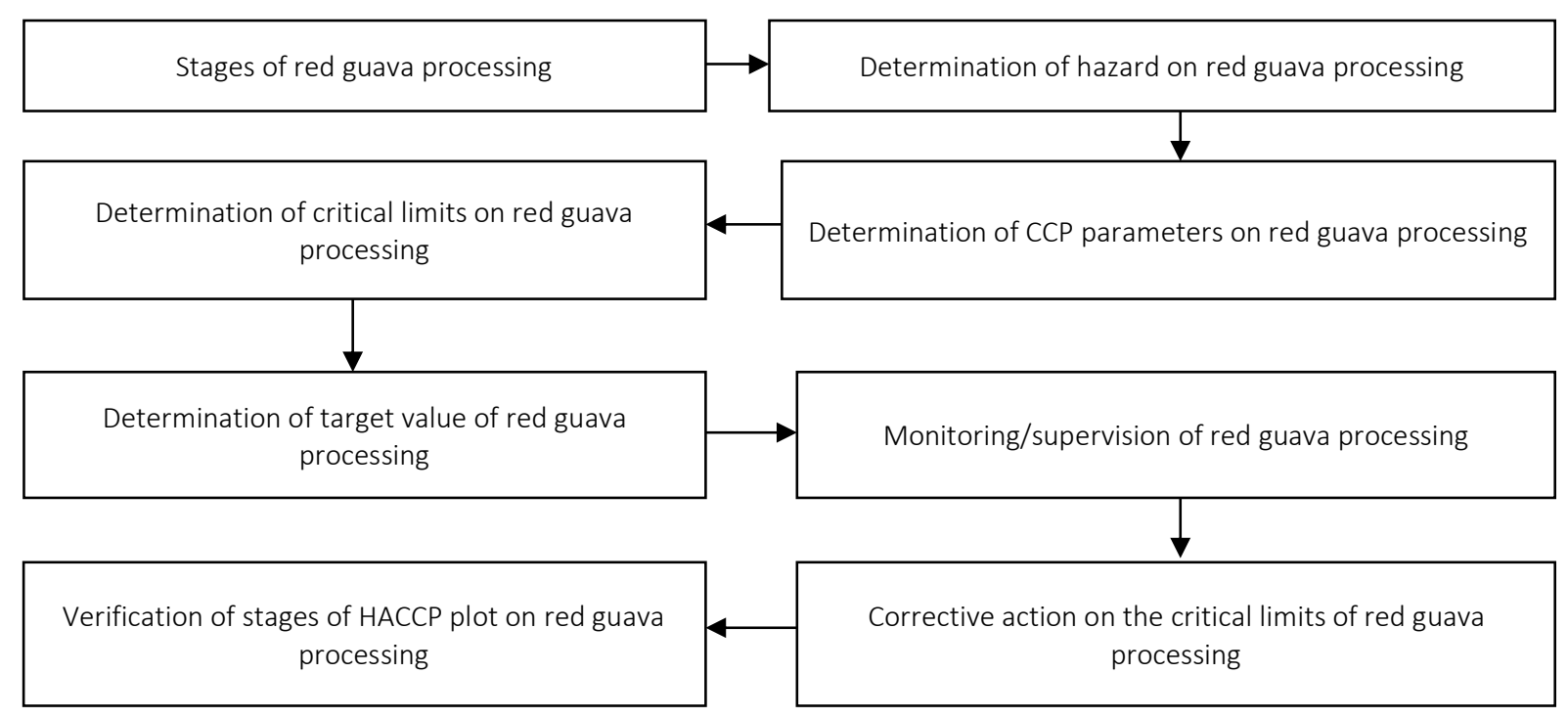

Figure 3. Plot of HACCP Preparation Planning on Red Guava Proccessing

Source: Data Processed, 2016

\section{DISCUSSION}

\section{Stage of Raw Material Receipt Process}

(1) This stage shows the existence of physical, chemical and biological hazards on raw materials. The hazards include: a) the presence of foreign body contamination (sand, gravel, etc.) and pesticide residues, toxins in the red guava; $b$ ) the presence of preservatives (sodium bisulfite) in palm sugar; and $c$ ) the presence of toxic fungi in the coconut.

(2) CCP parameters determined in this stage include: a) the presence of foreign body contamination, such as gravel and sand and chemical substances in red guava; b) the presence of chemical substances in palm sugar; and c) the content of toxic fungi in coconut.

(3) Critical limits determined at this stage include: a) the presence of foreign bodies in the red guava and pesticide residues in the red guava; $b$ ) the presence of preservatives in palm sugar; and c) the presence of toxic fungi in coconut.

(4) The target values determined in this stage include: a) the absence of foreign body contamination and the absence of pesticide residue content in the guava; b) absence of preservatives in palm sugar; and c) the absence of toxic fungi in the coconut.

(5) Monitoring conducted at this stage includes: a) monitoring of types of foreign bodies in the red guava, how is the control to red guava suppliers, whether there is no pesticide content in red guava, and how is the control of red guava suppliers; b) whether there are preservatives in palm sugar and how is the control to supplier, visual checking on palm sugar; and c) whether there are toxic fungi in coconuts and how is the control to suppliers storing the coconut in a dry place. Monitoring is performed at each stage process.

(6) Corrective action at this stage is determined as follows: a) control of red guava raw material suppliers; b) control of suppliers with appropriate palm sugar selection; and c) control of suppliers storing coconut in a dry place.

(7) Verification at this stage is determined by: a) the guava is free from foreign body contamination and pesticide; b) palm sugar is free from preservatives; and c) coconut is free from toxic fungi.

\section{Stage of Washing and Cutting Red Guava}

(1) This stage indicates the presence of physical hazard at the time of washing and cutting the red guava. The hazard is the presence of foreign body contamination (hair, nails, dust, and others). 
(2) CCP parameters determined in this stage are the presence of foreign body contamination in the process of washing and cutting the red guava.

(3) Critical limits determined in this stage is the presence of foreign body contamination.

(4) Target value determined in this stage is the absence of any foreign body contamination.

(5) Monitoring undertaken at this stage is whether there is any foreign body contamination and how to visually check and sanitize workers conditions. Monitoring is performed at each stage process.

(6) Corrective action at this stage is performing checking and workers sanitation.

(7) Verification at this stage is a stage of free from workers and equipment contamination.

\section{Stage of Smoothing the Red Guava Using a Blender}

(1) There is an identified physical hazard at the stage of smoothing the red guava using a blender, which is the contamination of foreign bodies (hair, nails, and dust).

(2) CCP parameters determined at this stage is the presence of foreign body contamination in the blender process.

(3) Critical limits determined at this stage is the presence of foreign body contamination.

(4) Target value determined at this stage is the absence of any foreign body contamination.

(5) Monitoring conducted at this stage is whether there is foreign body contamination and how to visually check and sanitize workers. Monitoring is performed at each stage process.

(6) Corrective action at this stage is to check and sanitize workers.

(7) Verification at this stage is the stage of smoothing and cutting process that is free from foreign body contamination.

\section{Stage of Filtering Blended Red Guava to Separate between the Guava Juice and the Seeds}

(1) There is an identified physical hazard of stage of filtering blended guava to separate between the guava juice and the seeds, namely the presence of foreign body contamination (hair, nails, dust, and others.

(2) CCP parameters determined at this stage are the presence of foreign body contamination in the filtration process.

(3) Critical limits determined at this stage are the presence of foreign body contamination.

(4) Target value determined at this stage is the absence of any foreign body contamination.

(5) Monitoring undertaken at this stage is whether there is foreign body contamination and how to visually check and sanitize workers. This monitoring is performed at each stage process.

(6) Corrective action at this stage is to check and sanitize workers.

(7) Verification at this stage is that the filtering process is free from foreign body contamination.

\section{Stage of Mixing}

(1) There is an identified physical and biological hazards in stage of mixing. The hazard is the presence of foreign body contamination (dust and hair) and flies.

(2) CCP parameters determined at this stage is the presence of foreign body contamination in the stirring process and flies flying around the mixing and stirring spots.

(3) Critical limits determined at this stage is the presence of foreign body contamination and flies in the mixing and stirring process.

(4) Target value determined at this stage is the absence of foreign body contamination and flies in the mixing and stirring process.

(5) Monitoring undertaken at this stage is whether there is foreign body contamination and flies in the stirring and mixing process, and how is the visual checking, worker sanitation, visual observation on flies around the stirring and mixing process. Monitoring is conducted once in the stage process.

(6) Corrective action taken at this stage is to check and sanitize workers and work environment control. 
(7) Verification at this stage is a stirring process that is free from foreign body contamination, and mixing and stirring process that is free of flies.

\section{Stage of Stirring Guava Juice}

(1) There is an identified biological hazard in the stage of stirring guava juice. The hazard is the presence of workers and equipment contamination.

(2) CCP parameters determined at this stage are the presence of workers and equipment contamination.

(3) Critical limits determined at this stage are the presence of cross contamination between workers and equipment.

(4) Target value at this stage is the absence of workers and equipment contamination.

(5) Monitoring undertaken at this stage is whether there is workers and equipment contamination and how is the sanitation to workers and equipment.

(6) Corrective action taken at this stage is to maintain sanitation of workers and equipment.

(7) Verification at this stage is a stirring process that is free from workers and equipment contamination.

\section{Stage of Coconut Grating}

(1) There is an identified physical hazard in the stage of coconut grating. The hazard is foreign body contamination (coconut fiber).

(2) CCP parameters determined at this stage are the presence of foreign body contamination (coconut fiber) in the grating process.

(3) Critical limits determined at this stage are the presence of foreign body contamination.

(4) Target value determined at this stage is the absence of any foreign body contamination.

(5) Monitoring performed at this stage is whether there is foreign body contamination in the form of coconut fiber and how is the soaking process of coconut after peeled. This monitoring is performed in each stage process.

(6) Corrective action taken is to soak the coconut after peeling.

(7) Verification of action at this stage is grated coconut free from foreign body contamination.

\section{Stage of Boiling}

(1) There is an identified biological hazard in the stage of boiling. The hazard is workers and equipment contamination.

(2) CCP parameters determined at this stage are workers and equipment contamination.

(3) Critical limits determined at this stage are the presence of cross contamination between workers and equipment.

(4) Target value determined at this stage is the absence of workers contamination.

(5) Monitoring undertaken at this stage is whether there is workers and equipment contamination, and how is the sanitation of workers and equipment. This monitoring is performed in each stage process.

(6) Corrective action taken is to maintain the sanitation of workers and equipment.

(7) Verification of action taken at this stage is the boiling process that is free from workers and equipment contamination.

\section{Stage of Pouring Dough into Baking Sheet}

(1) There are identified biological hazards in the stage of pouring dough into baking sheet. The hazards are flies and equipment contamination.

(2) CCP parameters determined are the presence of equipment contamination and flies.

(3) Critical limits determined at this stage are the presence of equipment contamination and flies.

(4) Target value determined at this stage is the absence of workers contamination and flies. 
(5) Monitoring undertaken at this stage is whether there is equipment contamination and flies and how are the sanitation and equipment at this stage. Monitoring is performed at each stage process.

(6) Corrective action taken is to maintain the sanitation and equipment.

(7) Verification at this stage is that the process of puring dough into baking sheet that is free from equipment contamination and flies.

\section{Stage of Printing and Packaging}

(1) There is an identified physical hazard in the stage of printing and packaging. The hazard is the presence of foreign body contamination (hair and nails).

(2) CCP parameters determined at this stage are the presence of foreign body contamination in the printing process.

(3) Critical limits determined at this stage are the presence of foreign body contamination.

(4) Target value determined at this stage is the absence of any foreign body contamination.

(5) Monitoring undertaken at this stage is whether there is foreign body contamination and how is the visual checking and workers sanitation. Monitoring is performed in each stage process.

(6) Corrective action taken at this stage is to check and sanitize workers.

\section{Verification at This Stage is that the Printing is Free from Foreign Body Contamination}

Processed red guava products that have been manufactured can be packed so that the products can be marketed. Packaging of a product must meet the following criteria: 1) the packaging shall be in accordance with the physical facilities and equipment for the packaging process (such as the suitability of UHT method, aseptic packaging, tetrapack, etc., and packaging materials used are bottles etc.); 2) the packaging shall be in accordance with the product characteristics for the purpose of (such as proper selection of packaging materials used with the physical form of products such as (gas, liquid and solid), product integrity and stability, recyclability, etc.); 3) the packaging shall be in accordance with the consumer's requirements for the physical characteristics of the product (such as product weight, ingredients, size, recyclability, reclosability, transposibility, and the product in accordance with consumer preference); 4) the packaging shall be in accordance with consumer preferences related to cognitive characteristics (such as consumer perceptions of product quality); and 5) packaging serves as the embodiment of product brand for marketing purposes (Paz-Gonzales et al., 2007).

Institution has been applied to processed red guava products in Tambahrejo Village (Hamid and Susilo, 2011). Gapoktan (Joint Farmers Group) of Tambahrejo Village processing red guava into processed products has established a cooperation with farming groups located in other areas in Kendal Regency, so as to form a cluster of red guava. This cluster consists of 641 members of red guava farmers and 29 administrators. This cluster area includes four sub-districts, namely Patean, Sukorejo, Plantungan and Pageruyung sub-districts. The cluster was formed with the aim of increasing production and cooperation in marketing, so that it can increase sales volume of processed products and increase the increase the income of guava farmers (Hermawan, 2016). In addition to forming cluster, red guava processing institution also requires cooperation with the government, local people, and external parties (educational institutions, investors and others) as shown in Figure 4. The business actors of Gapoktan can make audiences with the Government through the Agriculture Department as an effort to solve the problems and simultaneously convey the aspirations of the local community about red guava (Sandriana et al., 2015). In addition, Gapoktan can discuss problems with external parties such as educational institutions to obtain advice/input related to the problems occuring in the processing of red guava. 


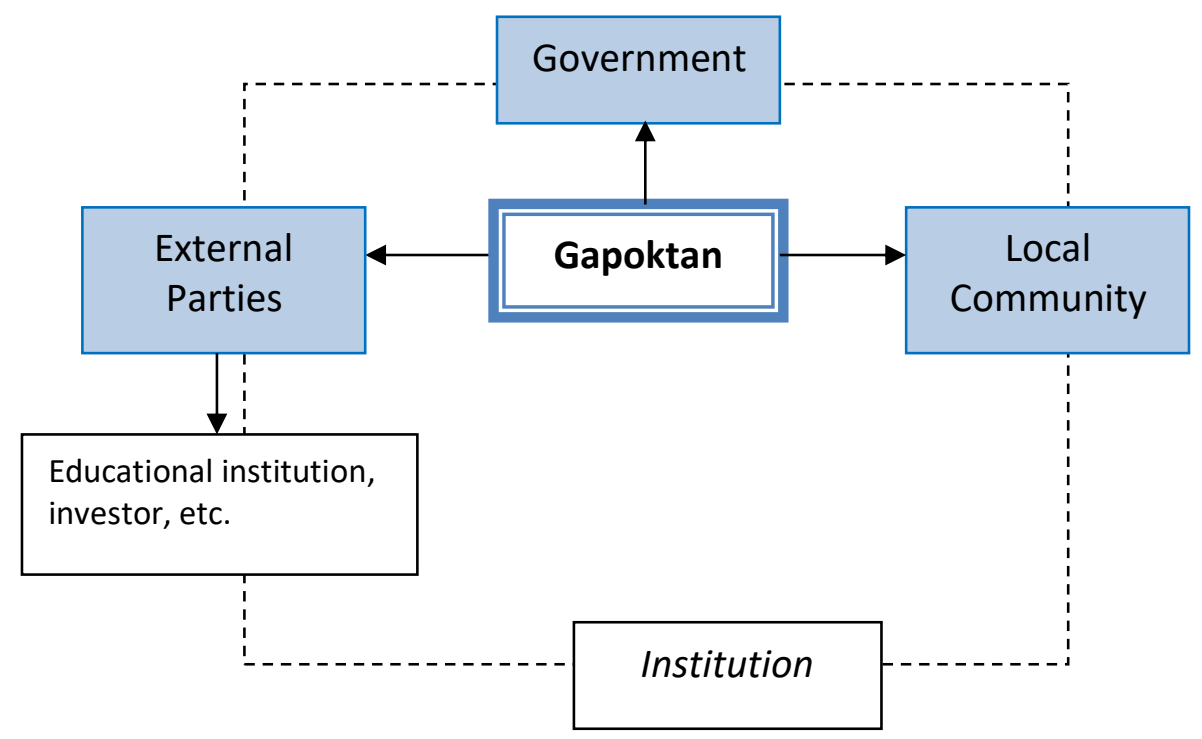

Figure 4. Institution of Processed Red Guava Products

Source: Data Processed, 2016

\section{CONCLUSION}

The agricultural sector is the leading sector in Tambahrejo Village with horticulture subsector product in the form of red guava production. The local community of Tambahrejo Village processes the red guava into a processed product. The red guava processing is performed with the aim to develop the innovation of farmers to increase the selling value of red guava, so that the consumers are attracted to the processed product. One of the processed red guava products is jenang.

Hazard Analysis Critical Control Point is required in the processed red guava product with the aim to improve quality assurance and food safety in order to keep developing in accordance with consumer requirements. Food safety is the main and most important requirement of all existing parameters. In addition, there is an institutional implementation of red guava processing in the form of business cooperation. Gapoktan (Joint Farmers Group) that has been established by the farmer groups establishes cooperation with farmer groups located in other areas, such as Patean, Sukorejo, Plantungan and Pageruyung sub-districts to form a cluster of red guava in Kendal Regency.

The purpose of this cluster is to increase production and cooperation in marketing so as to increase the sales volume of processed product and increase the income of guava farmers (Prasnowo et al., 2017). Gapoktan of Tambahrejo Village also cooperates with the Government, local community, and external parties that can assist to increase the production of red guava processing in Tambahrejo Village.

\section{REFERENCES}

Ginting, E., Prasetiaswati, N., and Wdodo, Y. (2007). Increased usability and added value of small sized sweet potatoes through processing to be sauce and jam. Food Crop Science and Technology, 2(1), 110-122.

Hamid, E.S. and Susilo, Y.S. (2011). Strategy for the development of micro, small, and medium enterprises in the Special Province of Yogyakarta. Journal of Development Economics, 12(1), 45-55.

Hermawan, H. (2016). Impact of Nglanggeran Tourism Village development on the economy of local communities. Journal of Tourism, 3(2), 105-117.

Lalisang, I. (2017). Empowering palm farmers through diversification of processed water nira products. Community Service Journal, 23(4), 415-418.

Marsigit, W. (2010). Pengembangan Diversifkasi Produk Pangan Olahan Lokal Bengkulu untuk Menunjang Ketahanan Pangan Berkelanjutan. Agritech, 30(4), 256-264. 
Paz-Gonzales, M., Thornsbury, S., and Twede, D. (2007). Packaging as a tool for product development: Communicating value to consumers. Journal of Food Distribution Research, 6166.

Prasnowo, M.A., Khomaruddin, A., and Hidayat, K. (2017) Development strategy for small and medium industries of crackers production centers. Engineering and Science Journal, 1(1), 1724.

Sandriana, N., Hakim A., and Saleh C. (2015) Strategy for the development of cluster-based regional superior products in the City of Malang. Reformation, 5(1), 89-100. 